\title{
Gudrun Thiel
}

\section{An unusual encounter between Man and Death in the Middle Ages as portrayed in Der Ackermann aus Boehmen}

\begin{abstract}
This article tries to establish the uniqueness of the relationship between man and Death in Der Ackermann aus Boehmen. This is achieved by comparing Der Ackermann to disputes between man and Death of a similar kind and by resorting to possible sources for the depiction of the figure of Death. While Death's right to kill is in the end confirmed by God, man nevertheless has made inroads into Death's universal and indiscriminatory powers by emotional and intellectual accusations as well as physical threats. This was facilitated by personifying Death to such an extent that Death was brought close to the level of man rather than remaining a pseudo-transcendental power.
\end{abstract}

Der Ackermann aus Boehmen was written by Johannes von Tepl in approximately 1401 . He was born about 1350 in Saaz in Bohemia and probably attended the Latin school there. From 1388 onwards records exist proving that Johannes von Saaz (as he was also known) was both employed as city scribe and as principal of the school at Saaz. At some stage he may also have obtained a magister artium. In 1411 he moved to Prague where he served as city scribe. In 1413 he was already very ill and he died in 1415 leaving behind a wife called Clara and five children. Whether or not Johannes von Saaz's biography corresponds to the events recorded in Der Ackermann aus Boehmen critics have not been able to establish. If so, Johannes von Saaz's first wife, Margaretha, would have died in 1400 and Der Ackermann could be regarded as a biographically inspired work. 
Der Ackermann aus Boehmen ${ }^{1}$ consists of a dispute between Ackermann (literally meaning ploughman) and Death. A ploughman was thought by the critic, Burdach (1926-32:111-114), to represent Adam. Burdach, basing his interpretation on chapter 18 of Der Ackermann aus Boehmen, thus regarded Ackermann as symbolic of all mankind. However a later critic Philippson (1941:163-178), found that Ackermann actually referred to himself as a pusher of the pen (the pen being his plough). The possibility of such ambiguity with regard to the interpretation of Ackermann though shows that he is both, a representative of mankind in executing the most basic profession, that is cultivating and protecting earth, and an intellectual individual from the beginning of the fifteenth century. His opponent, Death, on the other hand, appears as a personification.

The dispute between Ackermann and Death starts with an accusation by Ackermann. It makes up thirty-two chapters of alternative speeches. Chapter 33 presents God's judgement and chapter 34 contains Ackermann's prayer for the soul of his wife.

The dispute between Ackermann and Death can be divided into different parts depending on whether the criteria used are sources, content structure or the genus iudiciale. The most prominent single source used for Der Ackermann is the Tractatus de crudelitate mortis. [See Hahn (1984:96-99) and Jaffe $(1963: 46-63)$.] This source only refers to chapters $1-18$ while the rest of the dispute is Johannes von Tepl's own compilation based in part on other sources. The differences between Der Ackermann and the Tractatus will be discussed at a later stage. In terms of content structure one could divide the dispute roughly into three parts: chapters 1-14 depict the dispute between Ackermann and Death on the death of Margaretha; chapters 15-18 are a self-representation of Death; chapters 19-32 depict Death's general attitude to life and Ackermann's right to lament death. The final chapters form a unit on their own. (Walshe (1954:130-145). This structural analysis shows that there is a distinct break in the work. The deeply emotional accusation of Ackermann in the first part has to give way under the pressure of Death's official power. In the second part, however, Ackermann's rational arguments get much closer to defeating Death than his former accusations and curses did. The genus iudiciale has been applied by different critics with slight variations in chapter divisions, for example: chapters 1-2: exordium, chapters 3-7: narratio, chapters 8-30: argumentatio, chapters 31-31: refutatio, chapters 33-34: peroratio (Baeuml, 1958:223-232). Thus, Johannes von Tepl has resorted to the commonly known juridical practice for rhetorical purposes. In a letter to a friend the author stresses the rhetorical quality of this work of prose. The juridical set-up of the work though also gives it a character of sternness and authority of a different kind than the biographical interpretation which sees the death of Johannes von Tepl's wife Margaretha in 1400 as the motive for writing Der Ackermann.

1. All references are made to the Reclam edition ed. by Felix Genzmer (1982). 
The content of the dispute between Ackermann and Death can shortly be summed up in the following way: Ackermann has recently lost his much beloved wife. As she was still young and especially virtuous, Ackermann feels deeply wronged by her death. Ackermann therefore appeals against Death to God. The dispute is then carried out between the two parties in the presence of God, and Death finally demands God's judgement.

Ackermann accuses Death vehemently of murdering his wife. Death in his souvereignty is prepared to listen to Ackermann. He admits having killed the virtuous and efficient wife. At the same time Death calls his deed a work of mercy as Margaretha has died with her honour and physical strength perfectly intact. Death then provides further proof of his righteousness. He is the lex naturalis and can neither be influenced by science, nor material riches nor personal feelings. He has been instituted by God to eradicate everything superfluous, to keep a natural balance on earth. Furthermore, Death understands himself as a counterpart of life already at work during a person's earthly life, that is the more happiness someone experiences the more sorrow he shall feel.

Ackermann has to acquiesce to Death's power but as he cannot accept that Death is acting on behalf of God he tries to get to know his opponent better.

Death then resorts to iconography and Greek as well as Christian mythology to describe his character. Achermann, however, accuses Death of not performing well according to his own definition. Death is not God's righteous Great Reaper where social status and ethical norms come into play. Here the higher estates (social ranks) and the evil people seem to be at an advantage because Death spares their life longer. Death's mockery at Ackermann's apparent wisdom once again humbles Ackermann and he tries to appeal to Death's humanity. Death should be forgiving and fair. He should provide a substitute for what he has taken away or give advice and help of how to overcome Margaretha's death. Otherwise Ackermann warns him he may even attack him physically.

As Death is incapable of providing substitution for what he has seized, a fact that Burdach (see Walshe, 1954:135) has described as a tragic turning-point in the dispute, Death resorts to giving advice. But Death's advice results in a total negation of the value of life and renunciation of everything that had been precious to Ackermann up to that point in time. As everyone has to die once he has been born, according to the lex naturalis, it is pointless to lament death. All life and all happiness have only been created in Death's view in order to die. Therefore man can only attain happiness in a stoic way by non-attachment to earthly goods. Death further reduces man to his physical components and claims that whatever beauty or wisdom man may have, it cannot absolve him from death. A woman can be a burden to a man, lust and avarice only invoke sin. Both, man and woman, therefore must die to make way for new life and to break free of the vicious circle of earthly striving and sinning. 
Ackermann, after having tried to establish the God-given value of man and woman finally lashes out to prove a logical mistake made by Death. Death cannot be the end of life and at the same time remain lord on earth after everyone has died. Under such circumstances Death could only find a place in hell.

Death makes a last attempt to show Ackermann the vanity and mobility of ever-changing life by referring to mining and agriculture. Death further establishes himself as the power that forces man to do good and keeps man in control as the hour of death remains uncertain for all.

Then Death takes Ackermann along with him before God's throne for judgement.

God grants both Death and man their right to exist and to dispute their grievances. God acknowledges that both parties have fought well. Ackermann is forced by his human sorrow to lament. Borck (1963:401-420) pointed out that the lamentatio nevertheless does not constitute an accusation against Death in God's eyes nor may Ackermann wallow in his sorrow and forget his soul. However, God rescues the honour of Ackermann and in his way recognises man's struggle for life.

Death, although reprimanded for the haughtiness with which he brags about the powers accorded him only on loan by God, is nevertheless granted victory as every man has to give his life to Death, his body to the earth and his soul to God.

In the final prayer Ackermann accepts God as the deus absconditus. God is accepted not only as the creator but just as much as the destroyer of life and happiness. In his way also the untimeous death of the individual, Margaretha, becomes part of God's order. God neither logically clarifies individual nor universal death. God's ways remain inaccessible to man and Ackermann can only ask for mercy for his wife.

Der Ackermann aus Boehmen depicts an unusual encounter between man and Death. For this reason it has been difficult to establish sources and influences on this work of literature. Great prominence is given by critics to the anthology of the Prague-Metropolitankapitel-Library marked O.LXXX² which had been in possession of the author Johannes von Tepl when he wrote Der Ackermann aus Boehmen. This collection includes: Seneca, De quatuor virtutibus cardinalibus; Richardus a S. Victore, De caritate; St. Bernhard, De contemptu mundi (maior); the Tractatus de crudilitate mortis; Bonaventura, Speculum seu Itinerarius; Augustinus, De honestate mulierum and a vado mort. Although all these writings are supposed to have influenced the work

2. Discovered by Doskocil (1961:67-102). 
to some extent, for our purposes, the Tractatus de crudelitate mortis is of special importance.

The Tractatus (Hahn, 1984) differs from Der Ackermann in that in the Tractatus Death first establishes himself as a power destroying everybody without making any distinctions, while in Der Ackermann Ackermann starts off by attacking Death. In the Tractatus the accusations against Death that he is greedy and without sympathy only follow in second place. In contrast to Der Ackermann the Tractatus distinguishes between two kinds of Death, the death of the body and the death of the soul. Death in the Tractatus does not so much uphold order as executor of the lex naturalis although this is also implied by a reference to overpopulation. Death rather sees himself a provoker of a virtuous life by inspiring man with fear. In this way Death furthers God's worship and good redeeming work. Death therefore associates himself with the Old Testament in the Tractatus. In Der Ackermann on the other hand Death mainly emphasizes his role as lex naturalis although Old Testament ideas feature as well. In line with this fact is that the advocatus mundi in the Tractatus does not elaborate as coherently on the social and ethical qualities of man in God's harmonious order of creation as in Der Ackermann. The Tractatus therefore can only serve as a source for the successful refutations of Ackermann's accusations against Death. Only the advocatus mundi is reprimanded in the Tractatus for overstepping his boundaries, not Death.

Other influences where exerted by the Stoa, St. Augustine, early and high scholasticism, mysticism, especially the Buch der Liebkosung and other writings by Johann von Neumarkt who was a mediator for Italian humanist thinking; and disputes, especially the well-known Dialogus Mortis cum Homine (Rupprich, 1970:393-400). From the above compilation it becomes clear that Der Ackermann is a mixture of new and old elements.

For some of the pictorial representations of Death critics have also tried to establish sources.

In chapter 16 Death uses the following imagery to answer Ackermann's questions on his nature. Death refers to a painting in a Roman temple where he is depicted as a blindfolded man sitting on an ox and fighting with a hoe and a shovel. He is surrounded by people attacking him with their various implements. This representation has attracted the attention of many critics. Hammerich (1960:17-25) in line with Bernt/Burdach (see Hammerich, 1963:259) and Antonin Hruby (1971:91-99) has attempted to explain Der Ackermann in the humanist tradition by linking it to northern Italian iconography. According to Hammerich Johannes von Tepl had visited Rome and mistaken an ancient Roman relief depicting Jupiter Dolichenus for the figure of Death.

Rosenfeld (1935:241 -247) sought to disprove the Italian links as according to 
him any meaningful similarities with Italian iconography stem from a time later than the production of Der Ackermann. Rosenfeld himself then attempted to establish links between Der Ackermann and northern French iconography. Only in the combination of different features used to depict Death, not in the method of combination, does the depiction of Death in Der Ackermann distinguish itself from French representations.

Huebner (1968:239-244) in turn tried to interpret Der Ackermann as a work of mainly German origin and linked the Roman picture in chapter 16 to references in vernacular lyric and meistersang.

In some ways picking up on Rosenfeld Palmer (1983:171-239) links the Roman picture to the Roman picture tradition modified by the representational arts as established by Rosenfeld. Palmer's problem is that he can only refer to the Roman picture tradition in general as the two collections Imagines fulgentii and Holcot's Moralitates written by British friars and read widely in Central Europe around 1400 themselves do not contain any picture descriptions of a fictitious Roman god called Death. Only those whose presence in Central Europe has not been attested contain picture descriptions of Death.

All explanations for the source of the Roman picture therefore remain conjectures. This again can be viewed as proof that the encounter between man and Death is depicted in an original way in Der Ackermann.

As has become evident from the above establishment of sources the most meaningful comparison between Der Ackermann and an earlier work is the one with the Tractatus. One of the main points that Johannes von Tepl took over from the Tractatus is the idea of damnation and even physical destruction of Death (Jaffe, 1963).

This can be seen most clearly in the struggle of the defiant men and women in the Roman picture who use their tools in battle against Death. In the Tractatus the world succumbs to Death defiantly. Man knows that the fear inspired by Death serves to promote good deeds and that this can spare man from eternal damnation in hell.

Ackermann in contrast does not accept the following promise made by Death:

Wie gehessig du vns bist, wir wellen dir wunschen vnd gunnen, das dein sele mit der iren dort in himelischer wonung, dein leib mit dem iren bein bei beine alhie in der erden gruft wesen solten. Burge wolten wir dir werden: irer guttat wurdestu geniessen. (ch. 14) (Translation: Though you have been mean to us we wish you and do not begrudge you that your soul may rest with hers in the heavenly abode and that your body may be united with hers in the grave. I'll pledge to you: you shall enjoy the fruit of her goodness.)

In Der Ackermann it takes God Himself to persuade Ackermann to accept his 
fate. Ackermann must learn that his life is part of a higher order which he cannot understand.

In order for man to be able to struggle against Death in a verbal as well as in a physical way, with arguments, damnations and tools, Death had to be brought onto the same level as man. Therefore Death had to be personified. In this way Death who in Christian tradition did not exist as a persona to be believed assumes a reality similar to that of angles and devils. Thus Death becomes an autonomous power by himself.

The personification of the event of death enables man to cope with death. While certain iconographic or pseudo-iconographic representations are used to depict the functions and character traits of Death the very fact that Death appears in a personified form enables man to attack Death and, as some modern interpretations have shown, also to cope with death psychologically. [See Muller (1982:253-281); Schnyder (1984:1039-1051).]

As a personification Death becomes vulnerable both physically, emotionally and spiritually. While the physical side explicitly occurs only in the Roman picture, Ackermann's introductory speech indicates that Death is assumed to be as vulnerable as any human being.

Got, ewer tirmer, hasse euch, vnselden merung wone euch bei, vngeluck hause gewaltiglich zu euch: zumale geschant seit immer! Angst, not vnd jamer verlassen euch nicht, wo ir wandert; leit, betrubnuss vnd kummer beleiten euch allenthalben; leidige anfechtung, schentliche zuversicht vnd schemlich verserung die betwingen euch groblich an aller stat; himel, erde, sunne, mone, gestirne, mer, wag, berg, gefilde, tal, awe, der helle abgrunt, auch alles das leben vnd wesen hat, sei euch vnholt, vngunstig vnd fluchen euch ewiglichen! In bosheit versinket, in jamerigem ellende verswindet vnd in der vnwiderbringenden swersten achte gotes, aller leute vnd ieglicher schepfung alle zukunftige zeit beleibet! Vnerschampter bosewicht, ewer bose gedechtnuss lebe vnd tauere hin on ende; grawe vnd forchte scheiden von euch nicht, ir wonet wo ir wonet: (ch. 1) (Translation: May God your creator hate you, may growing calamity stay with you, may misfortune afflict you mightily, be fully disgraced for ever! May fear, predicament and woe not leave you wherever you go; sorrow, misery and grief shall accompany you everywhere; may accursed enmity, shameful disdain and ignominious aversion afflict you deeply in every place! May Heaven, earth, sun, moon, stars, sea, waters, mountain, fields, valley, meadow, and abyss of hell, everything that has life and being be ungracious, ill-disposed towards you and swear at you eternally! Wallow in evil, vanish in pitiful misery and remain for all future times under the irrevocable most severe ban of God, all people and all creatures. Imprudent 
rogue, may your malevolent memory live and remain without end; may horror and dread not part from you wherever you stay or go!)

Without the reduction of Death to a being similar to man Ackermann's appeal to Death's mercy would be meaningless: "Werlich were icht gutes an euch, es solte euch selber erbarmen. [...]" (ch. 7) (Translation: Truly, if there were something good about you, even you would have mercy.)

An euch kan niemant icht gutes verdienen; nach vntat wellet ir niemant genug tun, niemant wellet ir ergetzen. Ich prufe: barmherzigkeit wonet nicht bei euch; fluchens seit ir gewonet; genadenlos seit ir an allen orten. (ch. 13) (Translation: No one can gain anything good from you; after doing wrong you will not give recompensation to anyone, you will make no one happy. I note: mercy does not stay with you; you are used to cursing; you are merciless everywhere.)

Ackermann could not appeal to Death for advice, help or recompensation either nor could he set himself as an ethical example to Death if Death had not been personified.

But the most interesting aspect of the personification of Death in Der Ackermann is that this enables Johannes von Tepl to introduce an autonomous figure of Death. Ackermann says to Death,
Auch weiss ich wol, das solches gewaltes sunder goi vnd ewer niemant ist gewaltig. So bin ich von got nicht also geplaget: wann hette ich missgewartet gen gote, als leider dicke geschehen ist, das hette er an mir gerochen oder es hette mir widerbracht die wandelsone. Ir seit der vbelteter. (ch. 15) (Translation: I, too, know full well that besides God and you no one has the power to execute such violence. But I am certain that I am not plagued thus by God: if I had sinned against God, which unfortunately often happened, he would have avenged it, or the unblemished one would have made up for it. You are the evil-doer.)

In this way, Johannes von Tepl tries to justify evil in a God-given world, something that was only attempted philosophically much later in the Theodizee by Leibniz. Ackermann can now rebel against Death without attacking God. It enables him to ignore the lex naturalis in respect of God and to link righteous Death only to individual moral guilt. In this way Ackermann can accuse Death of acting unrighteously and give vent to his rage. Thus he can rebel against his fate. And God, in this way, is associated only with a harmonious cosmic and social life which is destroyed by the evil and chaotic force of Death. What has to change is thus not so much Ackermann's conception of Death but of God. God grants him the right to lament but he does not eradicate suffering and Death. 
As has been shown with regard to personification Death has been brought as close as possible to the level of Ackermann. This, as well as Ackermann's strong personal grief about his wife's death, his own feeling of moral innocence and remoteness from death but also his self-esteem from being God's most valued creation all supply him with self-confidence in his attacks on Death.

Furthermore, the devised distinction between God and Death as lex naturalis allows Ackermann to accuse Death of being amongst other things a murderer, a despiser, a robber, a thief, a bringer of sorrow, a calumniator, a rascal, a breaker of marriage, someone who does not provide recompensation, an attacker without warning, a false judge and unrighteous destroyer. In this way Ackermann links Death with the devil. Ackermann himself then in his opinion takes up God's point of view on Death.

Death like Ackermann though bases his authority on God: God has instituted Death in paradise. This installation Death understands as an order to reign on earth and therefore also to act as lex naturalis. Death understands himself in this way as a power of natural as well as of moral order by executing eternally unchanging laws of life.

What makes Death problematic in his self-understanding as a divine force is that he totally negates earthly life which has also been created by God. Furthermore, the imagery used to describe Death's functions and character emphasizes his brutality and callousness.

Death depicts himself in the following ways:

1. He portrays himself as being the Great Reaper, an epithet which is supposed to inspire the idea of fairness and universality in respect of nature and the estates. This characterisation is refuted by Ackermann who accuses Death of mowing arbitrarily and socially unevenly. The assumed fairness only consists of always fearing the event of the uncertain hour of death. In this way the "natural" and therefore softened image of Death is destroyed.

2. Death presents himself as a cloth maker through whose fullingmill all have to pass. He also sees himself as a cleaner of metal goods through whose rolling drum all have to go. Here again the principle of equality in Death is stressed. Everyone loses his individuality and becomes like the rest, both in standing and in bare physicality.

3. Death's unnaturalness is further depicted by his grotesque mount on an ox. His blindfold as well as the basilisk eyes from the comparison made by Pythagoras are again supposed to show Death's indiscrimination. The weapons of this knight consist of a hoe and shovel. Here agricultural implements and a grave digger's implements have been fused. Death kills with so-called natural tools and finally buries man with them.

4. The idea of an insidious and stealthy Death is portrayed by the represen- 
tation of Death as a hunter catching people with a net. Connected to this is the image of Death waylaying and driving man onto the road of death.

5. Death describes himself as a customs officer taking toll of every man's life. Here Johannes von Tepl includes an economic image which must have become a common feature in the blooming international trade-life of Bohemia.

6. Death also assumes the role of a preacher or at least a mentor on life. Having been instituted in paradise he obviously possesses an insight into life that Ackermann lacks. The contemptu mundi which Death advocates does however disregard the fact emphasized by Ackermann that the earth is God's creation. Death's advice can therefore only serve as a negation of earthly life, not as a plan to structure life on earth meaningfully. Death's last advice, "Iedoch kere vom dem bosen vnd tue das gute; suche den fride vnd tue in stete; vber alle irdische dinge habe lieb rein vnd lauter gewissen!" (ch. 32) (Translation: But turn away from evil and do good, look for peace and always keep it! More than all earthly things love a pure and clean conscience!) could be interpreted by Ackermann as something that he has already done.

7. To a certain degree Death even assumes the role of God when he promises Ackermann an eternal life together with his wife. Again Death evades the question of earthly life.

In contrast to Ackermann Death in many ways assumes roles that he also has in iconography, in the Dances of Death and in sixteenth century drama. Death as the Great Reaper, the hunter, the preacher with divine judgement and the grave-digger are widely known (Rosenfeld, 1954).

New are Death's industrial and commercial roles which are an indication of the development of widespread industry and trade. At the time when Johannes von Tepl wrote Der Ackermann aus Boehmen Bohemia produced one third of Europe's silver. The production of cloth was the most common industry with new materials and modes of production being developed at the time. New also, as has been pointed out earlier, is that Death places the main emphasis on being the executor of the lex naturalis rather than acting as an admonisher for sin.

Death in this way adapts to a new age both with respect of man's new activities and man's new feelings towards death, that is fearing physical decay.

Der Ackermann aus Boehmen must then be understood as a work of literature stemming from a transitional period.

Mueller (1982) has shown that the conception of a life orientated entirely towards eternity and therefore negating all earthly pleasures is the result of pre-Hus reform measures in Bohemia. These were part of the ascetic spiritual movement of Cluny and Hirsauer combating a church that had become too rich. The religious ideas expressed in Der Ackermann are therefore not 
mainly based on scholastic medieval theology which had been a mediation between earthly life and eternity. Death was fully in line with the ascetic reform movement when he emphasized the lex naturalis and maintained the point of view that all life has been created only in order to die. Death, however, takes the ascetic movement further into an entirely secular sphere when he, when defining himself, leaves out the theological component completely. He does not define himself as an entrance to eternal life but as the beginning of nothingness. This independence of the world from God was made possible by the distancing of God and the world of Occamism. For a short while Death became an entirely philosophical problem not linked to morals nor to physical decay. Then in the sixteenth century death was used once more by the church in order to make man penitent before God. Death, in Der Ackermann, therefore takes up a position that is connected both to the reform movement and early Humanism by opposition.

Ackermann also is no longer entirely in the medieval sphere. As we have seen, he does not accept death as part of life any longer. Ackermann is not an integral part of his society either, as he is confronted with Margaretha's death on his own. Death is for Ackermann a completely disruptive force but not for the reason that he fears eternal damnation. Nor is Margaretha's death only an end to his own material and reproductive possibilities. Margaretha was his emotional centre and with her death he enters into a process of individualisation. Therefore he at first fights against Death, then he asks for Death's advice on how to cope with Margaretha's memory. But this alone does not enable Ackermann to proceed with his earthly life. Death emphasizes though that Ackermann must only take care of his soul. This is an inner state not to be obtained by any special good work like becoming a monk. Ackermann also has to develop an individual relationship with God. In Occamism as we have seen the correlation between events on earth and God's acting was no longer evident. God became the deus absconditus (even if he is not expressly referred to as such in the Ackermann-text). Ackermann could now only form a relationship with God which was not based on logical insight into God's harmonious ways but depend on total trust and full acceptance that everything positive or negative was the divine will. He had to realise that world history as well as his own personal history were both governed by the deus absconditus. This feature especially emphasizes that Der Ackermann is not yet a humanist work but stems from a transitional period between the Middle Ages and Humanism. This is probably due to the fact that Bohemia experienced a very early Renaissance which was divorced from the general German humanist thinking eighty years later (Trillitzsch, 1981:19-20).

Der Ackermann aus Boehmen then is in many ways an experimental work. The use of the genus iudiciale coupled with a personification of Death that brings him down to an almost human level is new. Sources for the representational images have not yet been clearly established. The emotional and intellectual struggle of man against Death had never before been presented with such vigour. And Death does not primarily lead Ackermann to 
virtuousness, ascetiscism or penitence but to a new understanding of God. Ackermann still has to bow to Death willed by God but he has established his own honour as a human being as well.

\section{Bibliography}

Baeuml, F.H. 1958. Germanic Review 33,223-232.

Borck, K.H. 1963. Zeitschrift fuer Ostforschung 12,401-420.

Burdach, K. 1926-32. Der Dichter des Ackermann und seine Zeit. Berlin: Weidmann.

Doskocil, K. 1961. Sbornik historicky VII, 67-102.

Genzmer, G. 1963. Der Ackermann aus Boehmen. Stuttgart: Reclam.

Hahn, G. 1984. Der Ackermann aus Boehmen des Johannes von Tepl. Darmstadt: Wissenschaftliche Buchgesellschaft.

Hammerich, L.L. 1963. Festschrift Ulrich Pretzel. Berlin: Schmidt.

Hammerich, L.L. 1960. Humaniora, 17-25.

Hruby, A. 1971. Der Ackermann und seine Vorlage. Muenchen: C.H. Beck.

Jaffe, S.P. 1963. Festschrift H. -C. Roloff. Frankfurt/M.: P. Lang, 46-63.

Mueller, M.E. 1982. Einfuehrung in die deutsche Literatur des 12. bis 16. Jahrhunderts 2. Opladen: Westdeutscher Verlag, 253-281.

Palmer, N.F. 1983. Deutsche Vierteljahrsschrift 57, 171-239.

Philippson, E.A. 1941. Modern Languages Quarterly 2, 163-178.

Rosenfeld, H. 1954. Der mittelalterliche Totentanz. Muenster/Koeln: Boehlau

Rosenfeld, H. 1935. Zeitschrift fuer deutsches Altertum 72,241-247.

Rupprich, H. 1970. Die deutsche Literatur vom spaeten Mittelalter bis zum Barock (1): 1350-1520. Muenchen: C.H. Beck.

Schnyder, A. 1984. Schweizer Monatshefte fuer Politik, Wirtschaft, Kultur 64, 1039-1051.

Schwarz, E. 1968. Der Ackermann aus Boehmen des Johannes von Tepl und seine Zeit. Darmstadt: Wissenschaftliche Buchgesellschaft.

Trillitzsch, W. 1981. Der deutsche Renaissance-Humanismus. Leipzig: Reclam.

Walshe, M.O.C. 1954. Classica et Mediaevalia 15,130-145. 